\title{
Water requirements and crop coefficients of arugula grown in a protected environment
}

\author{
Requerimientos de agua y coeficientes de cultivo \\ de rúcula cultivada en un ambiente protegido \\ Danielle Paula de Oliveira Mangarotti ${ }^{1}$, Roberto Rezende ${ }^{1}$, Reni Saath ${ }^{1}$, \\ Tiago Luan Hachmann ${ }^{1}$, Claudia Salim Lozano ${ }^{1}$, Antônio Carlos Andrade Gonçalves ${ }^{1}$
}

\begin{abstract}
Maintaining an adequate water supply is essential to obtain maximum yields in vegetable crops. As such, this study aimed to determine the water requirements (ETc) and crop coefficients $(\mathrm{Kc})$ of arugula grown in a protected environment under subtropical climate conditions. The experiment was conducted in a greenhouse at the Center for Irrigation Technology of the State University of Maringá in Maringá, Paraná state (PR), Brazil. Crop evapotranspiration (ETc) was determined using three constant water table lysimeters and reference evapotranspiration with the Penman-Monteith equation. The total water consumption of the arugula crop was $113.27 \mathrm{~mm}$. The average values obtained for the crop coefficients in the initial, mid- and late-season stages were $1.92,1.03$ and 1.80 , respectively.
\end{abstract}

Key words: Eruca sativa, evapotranspiration, irrigation.

\section{RESUMEN}

Para cultivos hortícolas, mantener un suministro hídrico adecuado es esencial para obtener máximas productividades, por lo que se objetivó en este estudio determinar la demanda hídrica (ETc) y los coeficientes de la cultura $(K c)$ de la rúcula en invernadero. El experimento fue conducido en el Centro Técnico de Riego de la Universidad Estatal de Maringá, en Maringá - PR. Para la determinación de la evapotranspiración del cultivo $(E T c)$ se utilizaron tres lisímetros de compensación con nivel freático constante y para estimar la evapotranspiración de referencia $\left(E T_{o}\right)$ se utilizó la ecuación de Penman-Monteith. El consumo total de agua del cultivo de la rúcula fue de 113,27 mm. Los coeficientes del cultivo medios determinados fueron: estadio inicial 1,92, estadio intermedio 1,03 y estadio final 1,80.

Palabras clave: Eruca sativa, evapotranspiration, irrigation.

\section{Introduction}

Arugula, a leaf vegetable from the Mediterranean and Western Asia, rich in potassium (K), sulfur $(\mathrm{S})$, iron $(\mathrm{Fe})$ and vitamins $\mathrm{A}$ and $\mathrm{C}$, is popular in Brazilian regions settled by Italian immigrants (Jardina et al., 2017). In addition to its use as a food source, primarily in salads (Freitas et al., 2017), it is also considered a medicinal plant, with digestive, diuretic, laxative and anti-inflammatory properties in humans (Reghin et al., 2005).

Given the growing demand for this vegetable (Oliveira et al., 2010), greenhouse cultivation provides more efficient crop production and therefore better quality crops year round (Costa et al., 2011). However, this type of environment requires mandatory irrigation, making it vital to know the water requirements of the crop in order to rationalize and optimize water use (Oliveira et al., 2011; Oliveira et al., 2016).

It is important to estimate crop coefficients $(\mathrm{Kc})$ based on reference evapotranspiration to predict crop water requirements, evaporative capacity of the air, and phenological growth stage (Doorenbos \& Kassam, 2000). This parameter is related to environmental and plant physiological factors and should preferably be determined for the local conditions in which the plant will be grown (Lopes et al., 2011).

\footnotetext{
1 Universidade Estadual de Maringá, Maringá - Paraná, Brazil.

* corresponding author: danipbio@yahoo.com.br
} 
Despite the importance of irrigation, there is little information on the water requirements of arugula grown in protected environments under drip irrigation. In this context, the present study aimed to determine the water consumption and crop coefficients of arugula grown in a protected environment under subtropical climate conditions, throughout its growth cycle.

\section{Materials and methods}

The experiment was carried out from February to March 2017, at the Center for Irrigation Technology (CTI) of the State University of Maringá (UEM) in the municipality of Maringá, Paraná state (PR) ( $23^{\circ} 25^{\prime} \mathrm{S}, 51^{\circ} 57^{\prime} \mathrm{W}$ and altitude of $542 \mathrm{~m}$ ). The climate is classified as humid subtropical, according to Köppen's classification.

The experiment was conducted in a greenhouse with an arched roof, covered with $150 \mu$ m-thick polyethylene film and white shade cloth on the sides.

The soil in the experimental area is classified as Distroferric Red Nitisol (Embrapa, 2018). A rotary hoe was used to turn the soil and create 24 beds running across the greenhouse, each measuring $3 \mathrm{~m}$ long and $0.5 \mathrm{~m}$ wide. Fertilization was based on a chemical analysis of the soil and applied in accordance with the needs of the crop.

The Astro arugula variety was used and seedlings were grown in 200-cell expanded polyethylene (EPE) trays, containing a commercial coconut fiber substrate. The trays were kept in the greenhouse until transplanting, when plants displayed four true leaves.

Plants were spaced $0.30 \mathrm{~m}$ apart, with $0.125 \mathrm{~m}$ between rows.

Crop evapotranspiration (ETc) was determined inside the greenhouse using constant water table lysimeters placed in three of the beds. The lysimeters were made from $380 \mathrm{~L}$ PVC boxes $(1.05 \mathrm{~m}$ wide and $0.65 \mathrm{~m}$ deep) attached to an auxiliary device consisting of a water tank float valve and known volume water feeding system by flexible PVC tubing $(200 \mathrm{~mm})$. Two rows of arugula plants were transplanted into the lysimeters, reproducing the conditions of the beds, so that water extracted by the plants was automatically replaced by the system. Readings and water replacement in the tank were performed at 8 a.m. every day.

Reference evapotraspiration $\left(\mathrm{ET}_{\mathrm{o}}\right)$ was measured using a DAVIS weather station positioned in the center of the greenhouse, with data recorded on a datalogger.

The FAO Penman- Monteith method was used to determine $\mathrm{ET}_{\mathrm{o}}$ (Allen et al., 1998) in accordance with Eq. 1, as follows:

$$
\mathrm{ET}_{\mathrm{o}}=\frac{0.408 \Delta(\mathrm{Rn}-\mathrm{G})+\gamma \frac{900}{\mathrm{Tmed}+273} \mathrm{u}_{2}\left(\mathrm{e}_{\mathrm{s}}-\mathrm{e}_{\mathrm{a}}\right)}{\Delta+\gamma\left(1+0.34 \mathrm{u}_{2}\right)}
$$

where:

$\mathrm{ET}_{\mathrm{o}}=$ reference evapotranspiration $\left(\mathrm{mm} \mathrm{d}^{-1}\right)$;

$\Delta=$ slope of the vapor pressure curve $\left(\mathrm{kPa}^{0} \mathrm{C}^{-1}\right)$;

$\mathrm{Rn}=$ daily net solar radiation $\left(\mathrm{MJ} \mathrm{m}^{-2} \mathrm{~d}^{-1}\right)$;

$\mathrm{G}=$ daily soil heat flux $\left(\mathrm{MJ} \mathrm{m}^{-2} \mathrm{~d}^{-1}\right)$;

$\gamma=$ psychrometric constant $\left(\mathrm{kPa}^{0} \mathrm{C}^{-1}\right)$;

$\mathrm{T}=$ average daily air temperature $\left({ }^{0} \mathrm{C}\right)$;

$\mathrm{U}_{2}=$ average daily wind speed at a height of $2 \mathrm{~m}$ $\left(\mathrm{m} \mathrm{s}^{-1}\right)$;

$\mathrm{e}_{\mathrm{s}}=$ average daily saturation pressure of water vapor $(\mathrm{kPa})$;

$\mathrm{e}_{\mathrm{a}}=\quad$ average daily vapor pressure of water $(\mathrm{kPa})$.

The crop coefficients $(\mathrm{Kc})$ of arugula were determined based on the crop (ETc) and reference evapotranspiration $\left(\mathrm{ET}_{\mathrm{o}}\right)$ values, calculated daily, according to equation 2 .

$\mathrm{Kc}=\frac{\mathrm{ETc}}{\mathrm{ET}_{0}}$

To calculate mean Kc, the crop cycle was divided into three phenological growth stages, defined in accordance with Allen et al. (1998) as follows: I) initial stage, from day 1 to 8 ; II) midseason, from day 9 to 16 ; III) late-season, from day 17 until harvest (day 23).

The deterministic nature of the experiment means it does not fit any particular statistical design, since direct evapotranspiration readings were taken as opposed to testing treatments.

\section{Results and discussion}

The total amount of water applied to the arugula crop between transplanting and harvest was $113.27 \mathrm{~mm}$. Evapotranspiration for this period varied from 1.71 to $6.99 \mathrm{~mm}^{-1 a y}{ }^{-1}$ (Figure 1).

Cunha et al., (2013) studied water management and recorded water consumption of $134.2 \mathrm{~mm}$ and ETc values varying from 1.0 a $5.8 \mathrm{~mm} \mathrm{dia}^{-1}$ 


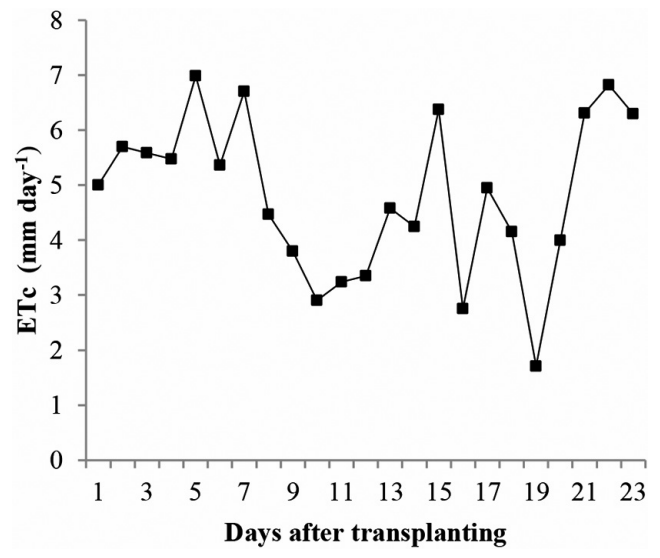

Figure 1. Crop evapotranspiration during the experiment. Maringá - PR.

during the growth cycle of an arugula field crop in Chapadão do Sul, Mato Grosso do Sul state (MS). In Sergipe state, Vasco et al. (2011) studied micro sprinkler-irrigated arugula and found ETc values between 0.50 and $5.90 \mathrm{~mm}$ day $^{-1}$.

The difference between the values reported by Cunha et al. (2013) and Vasco et al. (2011) and those observed here are attributed to the climate conditions at the cultivation site, demonstrating the relationship between the local climate and plant water consumption.

The main elements that affect crop evapotranspiration are temperature, relative humidity, wind speed and solar radiation, with the last considered the "driving force" of transpiration. As a result, several models have been proposed to estimate crop transpiration based on solar irradiance (Andriolo, 1999; Valandro et al., 2007). The Penman-Monteith method (FAO 56) is the standard recommended by the United Nations for food and agriculture.

Global solar radiation is closely related to the variation in crop evapotranspiration (Figure 2). The relationship between the transpiration rate of plants and global solar radiation allows accurate estimates of crop water consumption and production. In this scenario, based on intercepted or absorbed solar radiation data, higher radiation values were recorded in the initial stage of the arugula crop until eight days after transplanting (DAT), influencing ETc and increasing water consumption.

Solar radiation declined from 9 DAT onwards, which contributed to the decrease in crop evapotranspiration during this period (Figure 2). The greater the solar energy flow, the higher the

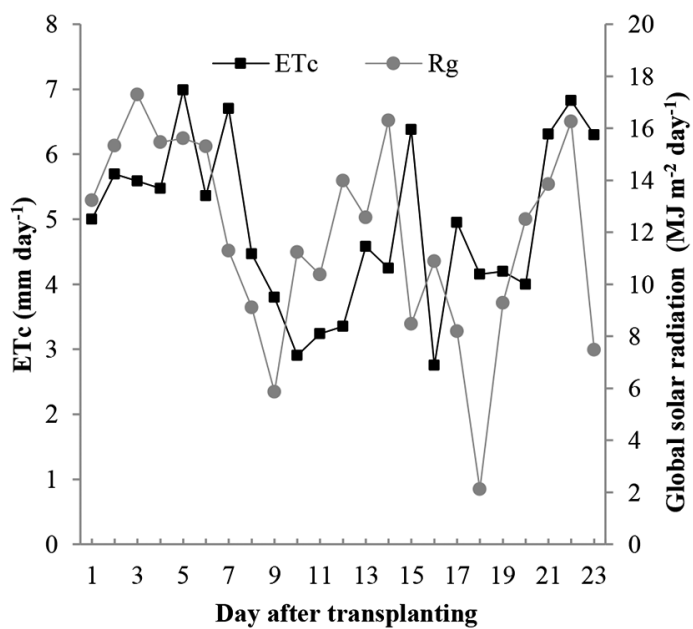

Figure 2. Variation in crop evapotranspiration and global solar radiation during the experiment. Maringá - PR.

temperature, resulting in increased transpiration (Tonello \& Teixeira Filho, 2012), which is the mechanism that plants use to protect themselves from excess solar radiation (Andriolo, 1999).

The maximum, average and minimum temperatures measured in the greenhouse during the experiment were $31.36 ; 29.35$ and $22.7^{\circ} \mathrm{C}$, respectively (Figure 3 ).

The average temperature in the greenhouse during the experiment varied from 26.66 to $29.85^{\circ} \mathrm{C}$ (Figure 3 ). When the temperature rose, relative humidity declined, representing an increase in the saturation deficit. In all probability, this factor directly affected the high water consumption of the crop (Table 1), since relative humidity

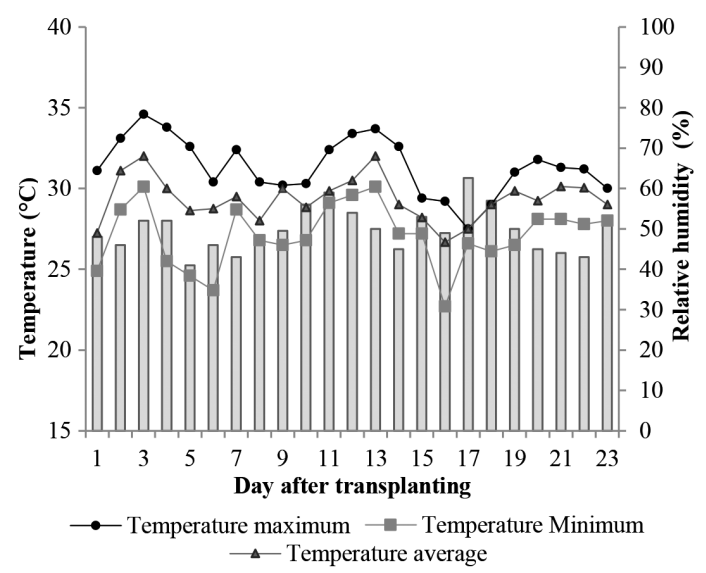

Figure 3. Relative humidity, maximum, average and minimum temperature inside the greenhouse. Maringá - PR. 
Table 1. Cop coefficients (Kc), crop evapotranspiration (ETc) and reference evapotranspiration (ETo) of arugula as a function of days after transplanting (DAT).

\begin{tabular}{ccccc}
\hline DAT & water consumption $(\mathrm{mm})$ & ${\text { ETo }\left(\mathrm{mm} \mathrm{day}^{-1}\right)}$ & ETc $\left(\mathrm{mm} \mathrm{day}^{-1}\right)$ & Kc \\
\hline $01-08$ & 45,28 & 2,93 & 5,65 & 1,92 \\
$09-16$ & 31,25 & 2,66 & 2,75 & 1,03 \\
$17-23$ & 39,50 & 2,91 & 5,24 & 1,80 \\
\hline
\end{tabular}

also determines the leaf-to-air vapor pressure gradient (VPG). This gradient is the driving force of water loss through transpiration, which tends to increase as the leaf-to-air VPG rises (Ismael Filho et al., 2015).

According to Ayars et al. (2003), ETc is a linear function of leaf area and only declines at the end of the growth cycle due to reduced photosynthesis and transpiration. It is important to note that, considering the period assessed, arugula differed from other crops because its highest water requirement was recorded in the initial and lateseason stages of the growth cycle (Table 1). This confirms that arugula crops consume more water at the end of the cycle, unlike most vegetables, which typically exhibit low late-season Kc values (Santana et al., 2016). Unlike fruiting vegetables and inflorescences, leaf vegetables are harvested before physiological maturity, meaning their photosynthetic activity does not decline, resulting in high ETc values even at the end of the growth cycle (Chitarra \& Chitarra, 2005).

Santana et al. (2016) calculated the crop coefficients of field-grown arugula irrigated with micro sprinklers in Uberaba, Minas Gerais state (MG), using a class A evaporation tank to determine $\mathrm{ET}_{\mathrm{o}}$ and soil-water balance for ETc. The authors found $\mathrm{Kc}$ values of $0.29 ; 0.93$ and 1.02 for the initial, mid-and late-season stages, respectively.

The differences in Kc values can be explained by climate variations and the different cultivation methods used in each experiment. The present study was carried out in summer and the predominant climate in Maringá is humid subtropical (Cfa), with cold dry winters and hot rainy summers, whereas Uberaba has a warm tropical climate (Aw) with hot rainy summers and cold wet winters, and the study was performed during winter.

It is important to underscore that the Food and Agricultural Organization of the United Nation's (FAO) Irrigation and Drainage Paper $\mathrm{N}^{\circ} 56$ (FAO 56) contains no specific recommended $\mathrm{Kc}$ for arugula, but rather general values of $0.70 ; 1.05$ and 0.95 for small leaf vegetables.As such, based on the ratio between crop (ETc) and reference evapotranspiration $\left(\mathrm{ET}_{\mathrm{o}}\right)$, the Kc values recorded here (Table 1) were higher in the initial and late-season stages than those recommended in FAO 56.

Allen et al. (1998) suggested that crop coefficient values be derived empirically for each crop, based on lysimetric data and local climate conditions, to prevent under or overestimating water requirements, which would negatively affect crop yield.

This justifies the need for local measurements, since coefficients depend on climate conditions, soil properties, the crop itself and irrigation methods.

\section{Conclusions}

The total water consumption of the arugula crop over the 23-day growth cycle was $113.27 \mathrm{~mm}$. The recommended coefficient values for drip-irrigated arugula grown in protected environments under subtropical climate conditions are 1.92, 1.03 and 1.80 in the initial, mid- and late-season stages, respectively. 


\section{Literature Cited}

Allen, R.G.; Pereira, L.S.; Raes, D.; Smith, M. 1998. Crop evapotranspiration: guidelines for computing crop water requirements. FAO Irrigation and Drainage Paper, 56. FAO. Rome, Italy. 300 p.

Andriolo, J.L. 1999. Fisiologia das culturas protegidas. Editora UFSM. 142 p. Ayars J.E.; Johnson, C.J.; Phene, T.J.; Trout, D.A.; Clark, R.M. 2003. Water use by dripirrigated late-season peaches. Irrigation Science, 22: 187-194.

Chitarra, M.I.F.; Chitarra, A.B. 2005. Pós-colheita de frutos e hortaliças: fisiologia e manuseio. Lavras: Esal/Faepe. 785 p.

Costa, C.M.F.; Seabra Júnior, S.; Arruda, G.R.; Souza, S.B.S. 2011. Desempenho de cultivares de rúcula sob telas de sombreamento e campo aberto. Semina: Ciências Agrárias, 32: 93-102.

Cunha, F.F.; Godoy, A.R.; Magalhães, F.F.; Castro, M.A. De; Leal, A.J.F.

2013. Irrigação de diferentes cultivares de rúcula no nordeste do Mato Grosso do Sul. Water Resouces and Irrigation Management, 2: 131-141.

Doorenbos, J.; Kassam, A.H.

2000. Efeito da água no rendimento das culturas. Campina Grande: Universidade Federal da Paraíba, 221 p.

EMBRAPA - Empresa Brasileira de Pesquisa Agropecuária. 2013. Solos: Sistema Brasileiro de Classificação de Solos. Ed. Embrapa Solos. Rio de Janeiro, Brasil. 353 p.

Freitas, E.M.; Giovanelli, L.B.; Delazari, F.T.; Santos, M.L.; Pereira, S.B.; Silva, D.J.H.

2017. Arugula production as a function of irrigation depths and potassium fertilization. Revista Brasileira de Engenharia Agrícola e Ambiental, 21: 197-202.

Ismael Filho, A.; Borges, P.F.; Araújo, L.S.; Pereira, A.R.;

Lima, E.M.; Silva, L.S.; Santos Junior, C.V.

2015. Influencia das variáveis climáticas sobre a evapotranspiração. Gaia Scientia, 9: 62-66.

Jardina, L.L.; Cordeiro, C.A.M.; Silva, M.C.C.; Sanches, A.G.;

Araújo Júnior, P.V.

2017. Desempenho produtivo e qualidade de cultivares de rúcula em sistema semi- hidropônico. Revista de Agricultura Neotropical, 4: 78-82.
Lopes, O.D.; Kobayashi, M.K.; Oliveira, F.G.; Alvarenga, I.C.A.; Martins, E.R.; Corsato, C.E.

2011. Determinação do coeficiente de cultura (Kc) e eficiência do uso de água do alecrim-pimenta irrigado. Revista Brasileira de Engenharia Agrícola e Ambiental, 15: 548-553.

Oliveira, J.M.; Rezende, R.; Freitas, P.S.L.; Maller, A.; Hara, A.T.; Santos, F.A.S.

2016. Fertirrigação na cultura da rúcula (Eruca sativa miller) conduzida em ambiente protegido. Irriga, 21: 438-448.

Oliveira E.Q.; Souza, R.J.; Cruz, M.C.M.; Marques, V.B.; França, A.C.

2010. Produtividade de alface e rúcula, em sistema consorciado, sob adubação orgânica e mineral. Horticultura Brasileira, 28: 36-40.

Oliveira, E.C.; Carvalho, J.A.; Rezende, F.C.; Freitas, W.A. 2011. Viabilidade técnica e econômica da produção de ervilha (Pisum sativum L.) cultivada sob diferentes lâminas de irrigação. Engenharia Agrícola, 31: 324-333.

Reghin, M.Y.; Otto, R.F.; Olinik, J.R.; Jacoby, C.F.S.

2005. Efeito do espaçamento e do número de mudas por cova na produção de rúcula nas estações de outono e inverno. Ciência e Agrotecnologia, 29: 953-959.

Santana, M.J.; Ribeiro, A.A.; Mancin, C.A.

2016. Evapotranspiração e coeficientes de cultura para a alface e rúcula cultivadas em Uberaba, MG. Revista Inova Ciência \& Tecnologia/Innovative Science \& Technology Journal, 2: 7-13.

Tonello, K.C.; Teixeira Filho, J.

2013. Transpiração e condutância estomática de Eucalyptus sp em resposta à radiação global e diferentes condições hídricas. Irriga, 18: 607-623.

Valandro, J.; Adeli Buriol, G.; Andriolo, J.L.; Heldwein, A.B. 2007. Transpiração do tomateiro cultivado fora do solo em estufa plástica e sua relação com os elementos metereológicos. Ciência Rural, 37: 1593-1600.

Vasco, A.N.; Aguiarnetto, A.O.; Mann, R.S.; Bastos, E.A. 2011. Irrigation management in real time for arugula crop in Sergipe. Journal of Agricultural Science and Technology, 13: 1161-1167. 
